\title{
The Affecting Factors of Jajar Legowo Planting Systems Adoption in Barumun Tengah District, Padang Lawas Regency
}

\author{
Rini Eli Anida ${ }^{1}$, Sri Fajar Ayu², Rulianda Purnomo Wibowo \\ ${ }^{1,2}$ Program Studi Magister Agribisnis Fakultas Pertanian Universitas Sumatera Utara \\ Corresponding Author: Rini Eli Anida
}

\begin{abstract}
Many things affect the increase in rice production, starting from the use of superior seeds, fertilizing the right target, proper irrigation, controlling pests and diseases, and so on. One way that farmers can choose is by planting lowland rice with the Jajar Legowo system. The main objective of the Jajar Legowo system is to increase the plant population by adjusting the spacing and manipulating the location of the plants, as if the rice plants were on the edge (edge crops). This study analyzes the effect of age, formal education, length of farming, land area, number of family dependents, land ownership, irrigation and income on the adoption of the Jajar Legowo planting system in Barumun Tengah District, Padang Lawas Regency. In this study, samples were taken as many as 120 lowland rice farmers who applied the Jajar Legowo planting system and those who did not apply the Jajar Legowo planting system. The data obtained through the distribution of questionnaires were processed using logistic methods and logit methods with SPSS tools. The results of this study indicate that the variables age, formal education, length of farming, land area, number of family dependents and land ownership status do not partially significantly increase the adoption of lowland rice farmers using the jajar legowo planting system technology innovation in Barumun Tengah District, Padang Lawas Regency. Irrigation and income variables have a significant effect on partially increasing the adoption of lowland rice farmers using the Jajar Legowo planting system technology innovation in Barumun Tengah District, Padang Lawas Regency.
\end{abstract}

Keywords: Rice Production, Jajar Legowo, Farmers, Planting Systems, Adoption

\section{BACKGROUND}

Barumun Tengah District is one of the districts in Padang Lawas Regency. In 2018 the production of lowland rice in Barumun Tengah District was 20,542.43 which is the second largest in Padang Lawas Regency. However, the average lowland rice production in Padang Lawas Regency is still low among other regencies / cities in North Sumatra Province. One of the efforts to increase food production is through innovation so that food self-sufficiency can be achieved. The government in Indonesia is looking for new breakthroughs to obtain optimal yields, namely by creating an agricultural system through agricultural intensification techniques, agricultural diversification, and agricultural extensification. One way that farmers can choose is by planting lowland rice with the Jajar Legowo system. The main objective of the Jajar Legowo system is to increase the plant population by adjusting the spacing and manipulating the location of the plants, as if the rice plants were on the edge (edge crops). Peripheral plants will get more sunlight which is very much needed in the growth of rice plants so that it has an effect on increasing rice production. That is why the Jajar Legowo system is an option in the process of increasing grain production.

The development of the Jajar Legowo farming system really depends on 
the awareness of the farmers towards the Jajar Legowo farming system. The level of farmer adoption of the Jajar Legowo farming system influences correct practice. Adoption is the decision to use a new idea entirely as the best way of acting. Of the total population of lowland rice farmers in Barumun Tengah District as many as 4250 people, farmers who have implemented the Jajar Legowo planting system are $60.83 \%$. Because there are still few farmers who apply the Jajar Legowo planting system, therefore it is necessary to conduct research on the adoption of the Jajar Legowo planting system in Barumun Tengah District, Padang Lawas Regency.

\section{Factors Affecting Innovation Adoption Age}

According to Soekartawi (1999), the average Indonesian farmer tends to be old and has a big influence on the productivity of the Indonesian agricultural sector. Older farmers usually tend to be very conservative (maintain) in response to changes to technological innovation. It's different with young farmers. According to Hasyim (2006), the age of the farmer is one of the factors that is closely related to the ability to work in carrying out farming activities, age can be used as a benchmark in seeing someone's activities at work if the age conditions are still productive, it is likely that someone can work well and maximum.

\section{Formal education}

According to Singarimbun and Penny in Soekartawi (1999), the number or length of school / education a person receives will affect his / her skills in a particular job. Of course, these skills will result in a greater ability to generate income for households. According to Hasyim (2006), the level of formal education that farmers have will show a broad level of knowledge and insight for farmers to apply what they get to improve their farming. Regarding the level of education of farmers, where those with higher education are relatively faster in implementing innovation adoption.

\section{Farming experience}

According to Soekartawi (1999), all experiences in the length of doing business play a very important role in determining individual judgment in order to move on to the next production process. The longer you work, the more experiences that are beneficial will encourage the individual to be more motivated to carry out optimal activities.

\section{Land area}

According to Soekartawi (1999), land area will affect business scale. The more land is used by farmers in agricultural business, the less efficient the land is. This is due to the idea that the size of the land will reduce efforts to take actions that lead to efficiency. On the other hand, on narrow land, efforts to control the use of production factors are getting better, so that agricultural business like this is more efficient. However, land that is too small tends to result in inefficient business as well.

\section{Number of Family Dependents}

According to Hasyim (2006), the number of family dependents is one of the factors that need to be considered in determining income in meeting their needs. The large number of family dependents will encourage farmers to carry out many activities, especially in seeking and increasing their family income. The more family members, the greater the burden of life that will be borne or must be fulfilled. The number of family members will influence farmers' decisions in farming (Soekartawi, 1999).

\section{Land Ownership Status}

Farmers who have large areas of land tend to have a positive response to new innovations because they have better economic capacity (Mardikanto, 1996) and the more land they cultivate, the greater the productivity of agricultural products they 
achieve. Apriani et al., (2018) stated that the more farmers who have status as land owners or not as cultivators, it will reduce technical inefficiency. Haryani, (2009) also states that landowners will achieve maximum results in managing their farms.

\section{Irrigation}

Irrigation is generally an activity related to obtaining water to support agricultural activities such as rice fields, fields or plantations. This effort involves making irrigation facilities and infrastructure, namely in the form of buildings and canal networks to carry and share water regularly to irrigation plots which are then used for the needs of the plants themselves (Pasandara and Tylor, 2007).

\section{Income}

Farming income and costs are influenced by internal and external factors. Internal factors consist of farmer age, education, knowledge, experience, skills, number of workers, land area and capital. External factors in the form of prices and availability of production facilities. The availability of production facilities and prices cannot be controlled by individual farmers even though the funds are available. If one of the products is not available, farmers will reduce the use of these production factors, as well as the price of production facilities, for example, the price of fertilizers is very high and even unreachable will affect costs and income (Suratiyah, 2015).

\section{Conceptual Framework}

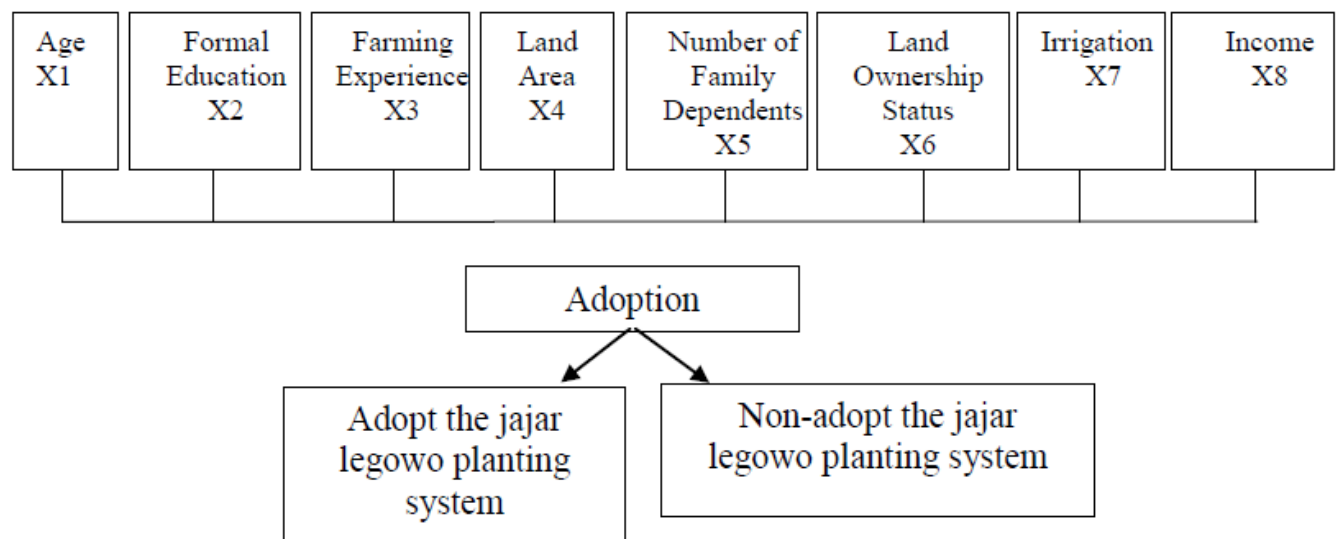

Figure 1. Schematic Framework

\section{Research Hypothesis}

Based on previous studies and problem identification that have been carried out, the following research hypothesis can be formulated: there is an effect of age, formal education, length of farming, land area, number of family dependents, land ownership status, irrigation and income on the adoption of the Jajar Legowo planting system.

\section{RESEARCH METHODS}

In this study the samples taken were lowland rice farmers who applied the Jajar Legowo cropping system and those who did not apply the Jajar Legowo cropping system. The number of samples in this study amounted to 120 samples, representing the population using purposive sampling method. The data obtained through the distribution of questionnaires were processed using logistic regression methods and to analyze problem identification the logit method with SPSS tools.

\section{RESULTS AND DISCUSSION}

The model used in the study of the factors that influence the adoption of the Jajar Legowo planting system in Barumun Tengah District, Padang Lawas Regency is 
a binary logistic regression model. The binary logistic regression model is used because the dependent variable is categorical data that is grouped into two categories, namely $\mathrm{Y}=1$ (applying the Jajar Legowo) and $\mathrm{Y}=0$ (not applying the Jajar Legowo).

Independent variables that are thought to affect the adoption of the Jajar
Legowo planting system include age, formal education, length of farming, land area, number of family dependents, land ownership status ( $1=$ self-owned, $0=$ rent $)$, irrigation $(1=$ using irrigation. , $0=$ not using irrigation), and income. Based on the results of data processing using SPSS 20, the results are as in Table 4.10.

Table 1. Logistic Regression Analysis Results

\begin{tabular}{|l|l|l|l|l|l|l|}
\hline Variabel & B & S.E. & Wald & df & Sig. & Exp(B) \\
\hline Farmer Age & $-0,016$ & 0,084 & 0,037 & 1 & 0,848 & 0,984 \\
\hline Formal education & 0,390 & 0,252 & 2,398 & 1 & 0,121 & 1,477 \\
\hline Farming Experiences & 0,054 & 0,075 & 0,511 & 1 & 0,475 & 1,055 \\
\hline Land area & $-1,303$ & 4,160 & 0,098 & 1 & 0,754 & 0,272 \\
\hline Number of Family Dependents & 0,111 & 0,301 & 0,137 & 1 & 0,711 & 1,118 \\
\hline Land Ownership Status & $-0,711$ & 1,343 & 0,280 & 1 & 0,597 & 0,491 \\
\hline Irrigation & $-2,490$ & 1,542 & 2,607 & 1 & 0,106 & 0,083 \\
\hline Income & 0,004 & 0,000 & 10,475 & 1 & 0,001 & 1,095 \\
\hline Constant & $-15,742$ & 5,834 & 7,281 & 1 & 0,007 & 0,000 \\
\hline
\end{tabular}

From the results of the logistic regression analysis, the following logistic regression equation is obtained:

$$
\begin{aligned}
& Y=\operatorname{Ln} \frac{p}{1-p}=-15,742-0,016 X_{1}+0,390 X_{2} \\
& +0,054 X_{3}-1,303 X_{4}+1,111 X_{5} 0,711 X_{6}- \\
& 2,490 X_{7}+0,004 X_{8}
\end{aligned}
$$

The Level of Adoption of Farmers to the Technological Innovation of the Jajar Legowo Planting System

Table 2. Farmers' Adoption Rate

\begin{tabular}{|l|l|l|l|}
\hline No & Category & Number & Percentage (\%) \\
\hline 1 & Adopted & 73 & 60,83 \\
\hline 2 & Non Adopted & 47 & 39,17 \\
\hline Total & 120 & 100 \\
\hline
\end{tabular}

Table 2 shows that lowland rice farmers in Barumun Tengah District, Padang Lawas Regency, are dominant $(60.83 \%)$ adopting the innovative Jajar Legowo planting system technology. This is because the lowland rice farmers in the study location can feel that the income is classified as medium-high, around $59.17 \%$ (Table 4.9). This is in accordance with the research of Herlina et al. (2019) which states that farmers' perceptions of Jajar Legowo technology innovation have an impact of $98.82 \%$ and as many as $62.5 \%$ of farmers have applied it to their agricultural land.

\section{Model Suitability Testing Hosmer and Lemeshow test}

Table 3. Hosmer and Lemeshow Test Results

\begin{tabular}{|l|l|}
\hline Test & Hosmer dan Lemeshow \\
\hline Chi-square & 2,836 \\
\hline Sig. & 0,944 \\
\hline
\end{tabular}

Table 3 shows that the Chi-square value obtained is 2.836 with a significance value of 0.944 (0.944>0.05), then accept $\mathrm{H} 0$, reject $\mathrm{H} 1$, meaning that there is no real difference between the data and the results of the logistic regression model prediction, or the model can predict the observation value of the logistic regression model and the appropriate model.

\section{Nagelkerke R Square test}

\begin{tabular}{|l|l|l|ll|}
\multicolumn{7}{|c|}{ Table 4. Nagelkerke R Square test results } \\
\hline Step & $\begin{array}{l}\mathbf{- 2} \text { Log } \\
\text { likelihood }\end{array}$ & $\begin{array}{l}\text { Cox \& Snell R } \\
\text { Square }\end{array}$ & $\begin{array}{l}\text { Negalkerke } \\
\text { Square }\end{array}$ & R \\
\hline 1 & 36,275 & 0,645 & 0,875 \\
\hline
\end{tabular}

Table 4 shows the Nagelkerke $R$ Square value of 0.875 , this indicates that the ability of the independent variable to explain the dependent variable is $87.5 \%$ and the other $12.5 \%$ is explained by other variables outside the model. 
Model Significance Testing Omnibus Test

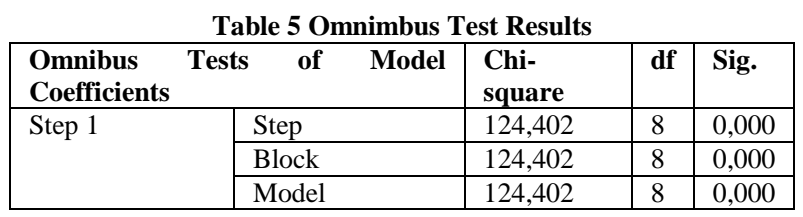

Table 5 shows that the Chi-square value obtained is 124.402 with a sig value of $0.000<0.05$, so there is at least one independent variable that significantly affects the dependent variable in the logistic regression model.

\section{Wald test}

Table 6 Wald test of lowland rice farmers adoption rate in use Jajar Legowo planting system technology innovation.

\begin{tabular}{|l|l|l|l|l|l|l|}
\hline Variabel & B & S.E. & Wald & df & Sig. & Exp(B) \\
\hline Farmer Age & $-0,016$ & 0,084 & 0,037 & 1 & 0,848 & 0,984 \\
\hline Formal education & 0,390 & 0,252 & 2,398 & 1 & 0,121 & 1,477 \\
\hline Farming Experiences & 0,054 & 0,075 & 0,511 & 1 & 0,475 & 1,055 \\
\hline Land area & $-1,303$ & 4,160 & 0,098 & 1 & 0,754 & 0,272 \\
\hline Number of Family Dependents & 0,111 & 0,301 & 0,137 & 1 & 0,711 & 1,118 \\
\hline Land Ownership Status & $-0,711$ & 1,343 & 0,280 & 1 & 0,597 & 0,491 \\
\hline Irrigation & $-2,490$ & 1,542 & 2,607 & 1 & 0,106 & 0,083 \\
\hline Income & 0,004 & 0,000 & 10,475 & 1 & 0,001 & 1,095 \\
\hline Constant & $-15,742$ & 5,834 & 7,281 & 1 & 0,007 & 0,000 \\
\hline
\end{tabular}

From the above results, it is obtained a significant value for the age variable of 0.878 where the significant value is greater than $\alpha(0.878>0.05)$, so accept $\mathrm{H} 0$ reject $\mathrm{H} 1$, meaning that the age variable (X1) has no effect on the adoption of the Jajar Legowo planting system (Y). This shows that the higher or older the farmers are, the higher the adoption of the Jajar Legowo planting system. The adoption of the Jajar Legowo planting system can be applied by anyone regardless of age.

The significant value of the formal education variable is 0.121 where the significant value is greater than $\alpha(0.121>$ 0.05), so accept $\mathrm{H} 0$ reject $\mathrm{H} 1$, meaning that the formal education variable (X2) has no effect on the adoption of the Jajar Legowo planting system (Y). The insignificant relationship between formal education and the adoption of the Jajar Legowo planting system shows that formal education does not affect the application of the Jajar Legowo because whatever the level of formal education of farmers, whether low or high levels of education have the same opportunity to implement the Jajar Legowo planting system.

The significant value of the old variable farming is 0.475 where the significant value is greater than $\alpha(0.475>$ $0.05)$, so accept $\mathrm{H} 0$ reject $\mathrm{H} 1$, meaning that the old variable farming (X3) has no effect on the adoption of the Jajar Legowo planting system in Barumun Tengah District. This is because the farming activities carried out by farmers are in accordance with hereditary experiences or habits, so that farmers already have their own concept or way of doing farming. Whereas jajar legowo is a new technology, so farmers tend not to apply it right away.

The significant value of the variable land area is 0.754 where the significant value is greater than $\alpha(0.754>0.05)$, so accept $\mathrm{H} 0$ reject $\mathrm{H} 1$, meaning that the variable land area (X4) has no effect on the adoption of Jajar Legowo planting system (Y). The insignificant relationship between land area and adoption of Jajar Legowo planting system shows that land area does not affect farmers in adopting Jajar Legowo planting system. Farmers who have wide and narrow land have the same opportunity to apply the row planting system. According to Soekartawi (1999), land area will affect the business scale. The more land is used by farmers in agricultural business, the less efficient the land will be. Conversely, on narrow land, efforts to control the use of production factors are getting better, so that agricultural business is more efficient.

The significant value of the variable number of family dependents is 0.711 where 
the significant value is greater than $\alpha$ (0.711> 0.05), so accept $\mathrm{H} 0$ reject $\mathrm{H} 1$, meaning that the variable number of family dependents (X5) has no effect on the adoption of the Jajar Legowo planting system (Y). According to Hasyim (2006), the number of family dependents is one of the factors that need to be considered in determining income in meeting their needs. The large number of family dependents will encourage farmers to carry out many activities, especially in seeking and increasing their family income.

The significant value of the variable land ownership status is 0.597 where the significant value is greater than $\alpha(0.597>$ 0.05), then accept $\mathrm{H} 0$ reject $\mathrm{H} 1$, meaning that the variable land ownership status (X6) has no effect on the adoption of Jajar Legowo planting system (Y). Farmers with their own or leased land have the same opportunity to adopt the Jajar Legowo planting system.

For irrigation variables, there is a significant effect at the significant level of $10 \%(0.1)$ on the adoption of the Jajar Legowo planting system (Y). This means that the irrigation variable has a significant effect on increasing the adoption of the Jajar Legowo planting system in Barumun Tengah District. Farmers with irrigated paddy fields have the opportunity to adopt the Jajar Legowo planting system by 0.083 times compared to farmers who do not get irrigation. Fuadi (2016) in his research on the study of water needs and water productivity of lowland rice with an SRI and conventional water supply system using pipe irrigation, states that the combination of using pipe irrigation with a water supply system can increase rice productivity. This study shows that water productivity is high in the presence of efficient water use.

From the above results also obtained a significant value for the income variable of 0.001 , where the significant value is smaller than $\alpha(0.001<0.05)$ so accept $\mathrm{H} 1$ reject $\mathrm{H} 0$, meaning that the income variable (X8) has a positive and significant effect on increasing the adoption of the Jajar Legowo planting system. in Barumun Tengah District, Padang Lawas Regency. For every one rupiah increase in income, the adoption rate of lowland rice farmers has increased by 1.095 times.

\section{Interpretation of Odd Ratio Value}

The method used to interpret the logistic regression parameters of categorical variables is the odds ratio. There are also categorical variables in this study, namely the variable of land ownership status (X6) and irrigation (X7). The magnitude of the odds ratio for a predictor variable $\mathrm{k}-\mathrm{k}$ is the value of Anti ln of ( $\beta i)$ or $\exp (\beta i)$ for $i=1$, ..., k.

\section{Odd ratio $=\exp (\beta i)$}

Meanwhile, the covariate variables are interpreted based on the Marginal Effect value. The covariate variables in this study were age (X1), formal education (X2), length of farming (X3), land area (X4), number of family dependents (X5) and income (X8). The following is the odd ratio value of each variable.

The following is a table of the odds ratio and marginal effect values of each variable in this study:

Table 7. Exp Value B, B, Pi, 1-Pi, and Ci

\begin{tabular}{|l|l|l|l|l|l|l|}
\hline No. & Variable & B & Exp B & Pi & $\mathbf{1 - P i}$ & $\mathbf{C i}$ \\
\hline 1. & X1 & $-0,016$ & 0,984 & 0,495 & 0,505 & - \\
2. & X2 & 0,390 & 1,477 & 0,596 & 0,404 & - \\
3. & X3 & 0,054 & 1,055 & 0,513 & 0,487 & - \\
4. & X4 & $-1,303$ & 0,272 & 0,213 & 0,787 & - \\
5. & X5 & 0,111 & 1,118 & 0,527 & 0,473 & - \\
6. & X6 & $-0,711$ & 0,491 & 0,329 & 0,671 & - \\
7. & X7 & $-2,490$ & 0,083 & 0,076 & 0,924 & - \\
8. & X8 & 0,004 & 1,095 & 0,329 & 0,671 & 0,026 \\
\hline
\end{tabular}

Table 7 shows that the marginal effect value of the income variable is 0.026 , meaning that each increase in farmer's income of 1 rupiah will increase the opportunity for farmers to adopt the Jajar Legowo planting system by $2.6 \%$. The size of the profits obtained becomes a consideration for farmers in deciding to adopt the Jajar Legowo planting system in Barumun Tengah District, Padang Lawas Regency. 


\section{CONCLUSION}

The variables of age, formal education, length of farming, land area, number of family dependents and land ownership status did not have a significant effect on partially increasing the adoption of lowland rice farmers using the Jajar Legowo planting system technology innovation in Barumun Tengah District, Padang Lawas Regency. Irrigation and income variables have a significant effect on partially increasing the adoption of lowland rice farmers using the Jajar Legowo planting system technology innovation in Barumun Tengah District, Padang Lawas Regency.

\section{Acknowledgement: None}

\section{Conflict of Interest: None}

\section{Source of Funding: None}

\section{REFERENCES}

1. Abdulrachman, A., \& Jamal E. 2007. Menjadikan Prima Tani sebagai Ujung Tombak Peningkatan Pendapatan Masyarakat Pedesaan. Lokakarya Nasional Akselerasi Diseminasi Inovasi Teknologi Pertanian. BBP2TP [Balai Besar Pengkajian dan Pengembangan Teknologi Pertanian]. Jakarta.

2. Alviana, E. D. 2018. Respon petani terhadap sistem tanam jajar legowo di Kecamatan Tumijajar Kabupaten Tulang Bawang Barat. Skripsi. Fakultas Pertanian, Universitas Lampung.

3. Andriani, E., \& Lubis, M. E. 2018. Pengaruh penerapan sistem tanam legowo terhadap budidaya padi sawah di Kecamatan Kampung Melayu Kota Bengkulu. AGRITEPA: Jurnal Ilmu dan Teknologi Pertanian, 5(2), 60-74. https://doi.org/10.37676/agritepa.v5i2.817.

4. Apriani, M., Rachmina, D., \& Rifin, A. 2018. Pengaruh Tingkat Penerapan Teknologi Pengelolaan Tanaman Terpadu (PTT) terhadap Efisiensi Teknis Usahatani Padi. Jurnal Agribisnis Indonesia, 6(2), 119132.

5. Aribawa, I. B. 2012. Pengaruh sistem tanam terhadap peningkatan produktivitas padi di lahan sawah dataran tinggi beriklim basah. In Prosiding. Seminar Nasional: Kedaulatan
Pangan dan Energi. Fakultas Pertanian Universitas Trunojoyo, Madura.

6. Asaad, M., Sugiman, S. B., \& Abidin, Z. 2017. Analisis persepsi petani terhadap penerapan tanam jajar legowo padi sawah di Sulawesi Tenggara. Jurnal Pengkajian dan Pengembangan Teknologi Pertanian, 20(3), 197-208.

7. Badan Pusat Statistik. 2016. Kabupaten Sumatera Utara dalam angka 2016. Badan Pusat Statistik Sumatera Utara, Medan

8. Badan Pusat Statistik. 2019. Kabupaten Sumatera Utara dalam angka 2019. Badan Pusat Statistik Sumatera Utara, Medan

9. Balai Pengkajian Teknologi Pertanian. 2006. Pengelolaan Tanaman dan Sumberdaya Tanaman Terpadu (PTT) Padi. Balai Pengkajian Teknologi Pertanian Banten.

10. Burano, R. S., \& Fadillah, A. 2020. Faktorfaktor yang mempengaruhi adopsi inovasi petani padi sawah di Kelurahan Padang Alai Bodi Kecamatan Payakumbuh Timur. Menara Ilmu, 14(2), 89-96. https://doi.org/10.31869/mi.v14i2.2270

11. Burhansyah, R., \& PontianakTelp, S. H. 2019. Faktor-faktor yang mempengaruhi adopsi inovasi pertanian pada Gapoktan PUAP dan non PUAP di Kalimantan Barat (Studi kasus: Kabupaten Pontianak dan Landak).

12. Effendy, L., \& Apriani, Y. 2018. Motivasi anggota kelompok tani dalam peningkatan fungsi kelompok. Jurnal Ekonomi Pembangunan. 10-24. http://dx.doi.org/10.35906/jep01.v4i2.270.

13. Effendy, L., \& Pratiwi, S. D. 2020. Tingkat adopsi teknologi sistem jajar legowo padi sawah di Kecamatan Cigasong Kabupaten Majalengka. Agrica Ekstensia, 14(1), 81-85.

14. Effendy, L., \& Yunika, C. 2020. Model peningkatan minat petani pada penerapan teknologi tanam jajar legowo padi sawah di Kecamatan Cikoneng Ciamis. AGRITEXTS: Journal of Agricultural Extension. 44(2), 75-83. https://doi.org/10.20961/agritexts.v44i2.454 01.

15. Farid, A., Romadi, U., \& Witono, D. 2018. Faktor-faktor yang mempengaruhi adopsi petani dalam penerapan sistem tanam jajar legowo di Desa Sukosari Kecamatan Kasembon Kabupaten Malang Provinsi Jawa Timur. Jurnal Penyuluhan, 14(1), 2732. 
https://doi.org/10.25015/penyuluhan.v14i1.1 9226.

16. Fuadi, N. A., Purwanto, M. Y. J., \& Tarigan, S. D. 2016. Kajian Kebutuhan Air dan Produktivitas Air Padi Sawah dengan Sistem Pemberian Air Secara SRI dan Konvensional Menggunakan Irigasi Pipa. Jurnal Irigasi, 11(1), 23. https://doi.org/10.31028/ji.v11.i1.23-32

17. Gujarati, D. 2012. Ekonometri Dasar. Terjemahan Sumarno Zain. Erlangga, Jakarta.

18. Harefa, C. D. 2019. Tingkat adopsi teknologi petani terhadap program peningkatan produktivitas padi sawah kasus: Desa Lubuk Bayas Kec. Perbaungan Kab. Serdang Bedagai.

19. Harinaldi. 2005. Prinsip- Prinsip Statistik untuk Teknik dan Sains. Jakarta: Erlangga

20. Haryani, D. 2009. Analisis Efisiensi Usahatani Padi Sawah pada Program Pengelolaan Tanaman dan Sumberdaya Terpadu di Kabupaten Serang Provinsi Banten. Tesis. Institut Pertanian Bogor: Bogor.

21. Hasanah, D. P. 2014. Analisis perbandingan pendapatan usahatani padi sistem tanam jajar legowo dengan sistem tegel Kelurahan Situmekar Sukabumi. Skripsi. Departemen Agribisnis Fakultas Ekonomi Dan Manajemen. Institut Pertanian Bogor, Bogor.

22. Hasyim, H. 2006. Analisis Hubungan Faktor Sosial Ekonomi Petani Terhadap Program Penyuluhan Pertanian. Penelitian LP Universitas Sumatera Utara, Medan.

23. Herlina, Y., Chozin, M., \& Romeida, A. 2019. Adopsi petani terhadap teknologi jajar legowo padi sawah di Kelurahan Rimbo Kedui Kecamatan Seluma Selatan Kabupaten Seluma. Naturalis. Jurnal Penelitian Pengelolaan Sumber Daya Alam dan Lingkungan, 8(2), 109-117.

24. Kartasapoetra. 1994. Aspek Teknis Informasi Penyuluhan Pertanian dan Peternakan. Penelitian Masyarakat Bogor. Bogor. Jawa Barat.

25. Lalla, H., \& Ali, M. S. S. 2012. Adopsi petani padi sawah terhadap sistem tanam jajar legowo 2: 1 di Kecamatan Polongbangkeng Utara, Kabupaten Takalar. J. Sains \& Teknologi, 12(3), 255-264.

26. Lubis, S. N. 2000. Adopsi Teknologi dan Faktor-Faktor yang Mempengaruhi. Universitas Sumatera Utara Press, Medan.
27. Malahayatin, D. M., \& Cahyono, E. D. 2017. Faktor kesesuaian dengan kebutuhan petani dalam keputusan adopsi inovasi pola tanam jajar legowo (Studi kasus petani padi di Kecamatan Widang, Kabupaten Tuban). Jurnal Ekonomi Pertanian dan Agribisnis, 1(1), 56-61.

28. Mardikanto, T. 1990. Tingkat Fungsional Penyuluh dalam Program Partisipasi Masyarakat. Penyuluhan Pertanian di Bogor, Jawa Barat.

29. Mardikanto, T. 1993. Penyuluhan Pembangunaan Pertanian. Sebelas Maret University Press. Surakarta.

30. Mardikanto, T. 1996. Penyuluhan Pembangunaan Kehutanan. Sebelas Maret University Press. Surakarta.

31. Mohaddesi, A., Abbasian, A., Bakhshipour, S., \& Aminpanah, H. 2011. Effect of different levels of nitrogen and plant spacing on yield, yield components and physiological indices in high-yield rice. American-Eurasian Journal of Agricultural \& Environmental Sciences, 10(5), 893-900.

32. Mulijanti, S. L., \& Sinaga, A. 2014. Efektivitas pendampingan teknologi tanam jajar legowo terhadap perubahan sikap dan pengetahuan petani di Kabupaten Sumedang Jawa Barat. Balai Pengkajian Teknologi Pertanian Jawa Barat.

33. Mulyani, T. 2001. Faktor Penentu Tingkat Adopsi Teknologi Usahatani Jagung (Studi Kasus di Desa Riak Siabun Kec. Sukaraja Kab. Bengkulu Selatan). Skripsi. Universitas Bengkulu.

34. Ningtyas, R. A., Astiti, N. W. S., \& Handayani, M. T. 2016. Tingkat adopsi sistem tanam jajar legowo 2:1 di Kelompok Tani Mina Sri Jaya Desa Sepanjang Kecamatan Glenmore Kabupaten Banyuwangi Jawa Timur. E-Jurnal Agribisnis dan Agrowisata, 5(2), 362-369.

35. Pasandaran, E., \& Taylor, D. C. 2007. Irigasi "Kelembagaan dan Ekonomi". Gramedia, Jakarta.

36. Permadi, N., Sunandar, B., \& Nurnayetti. 2013. Peningkatan produktivitas padi melalui inovasi teknologi spesifik lokasi untuk mencapai swasembada beras. In Prosiding Seminar Nasional Akselerasi Pemanfaatan Teknologi Pertanian Spesifik Lokasi mendukung Ketahanan Pangan dan Kesejahteraan Petani Nelayan. Badan Penelitian dan Pengembangan Pertanian 140-145. 
37. Purwono \& Heni, 2007. Budidaya 8 Jenis Tanaman Pangan Unggul. PT Penebar Swadaya. Jakarta.

38. Rizal, A. N., \& Nurfuadah, N. 2020. Tingkat adopsi inovasi pola tanam jajar legowo pada budidaya padi sawah di Desa Babakansari Kecamatan Sukaluyu Kabupaten Cianjur. AGRITA (AGri), 2(1), 46-54.

39. Rogers, Everett M. 2003. Diffusion of Innovations. New York: Free Press

40. Ryan, E., Mary, T., \& Johannes, H. 2018. Faktor-faktor yang mempengaruhi adopsi petani terhadap penerapan sistem pertanian jajar legowo di Desa Barukan Kecamatan Tengaran Kabupaten Semarang. Jurnal Seminar Nasional Dies Natalis UNS. 2(1), 53-64.

41. Santoso, S. 2010. Statistik Multivariat, Jakarta:PT Elex Media Komputindo.

42. Sastrawan, 2000. Adopsi Usahatani Jeruk di Kecamatan Seginim Kabupaten Bengkulu Selatan. Skripsi. Universitas Bengkulu.

43. Sekarmadjapahit. 2012. Tanam Padi Sistem Jajar Legowo. BPTP Banten

44. Septiana, A. F. 2016. Kajian Adopsi Inovasi Pola Tanam Jajar Legowo pada Usahatani Padi Sawah (Studi kasus pada Kelompok Tani Sekar Arum di Desa Pabuaran Kecamatan Salem Kabupaten Brebes) (Doctoral dissertation, Universitas Muhammadiyah Purwokerto).

45. Septiana, A. F. 2016. Kajian Adopsi Inovasi Pola Tanam Jajar Legowo Pada Usahatani Padi Sawah (Studi kasus pada Kelompok Tani Sekar Arum di Desa Pabuaran Kecamatan Salem Kabupaten Brebes). Skripsi, Universitas Muhammadiyah Purwokerto

46. Soekartawi. 1988. Prinsip Ekonomi Pertanian. Rajawali Press, Jakarta.
47. Soekartawi. 1999. Adopsi Inovasi Pengetahuan (Cognitive), Sikap (affective), Keterampilan (Psychomotoric). Jakarta : Rajawali Press.

48. Sukirno, S. 2002. Pengantar Teori Mikro Ekonomi. UI Press, Jakarta.

49. Suparwoto, S. 2010. Penerapan Sistem Tanam Legowo pada Usaha Tani Padi untuk Meningkatkan Produksi dan Pendapatan Petani. Publikasi Penelitian Terapan dan Kebijakan, 4(1) 1-7.

50. Suratiyah, K. 2015. Ilmu Usahatani. Edisi Revisi. Penebar Swadaya. Jakarta Timur.

51. Suriapermana S., Syamsul, I., \& Fagi, A. M. 1990. Laporan Pertama Penelitian Kerja Sama Mina Padi, antara Balittan Sukamandi-IDRC Canada. Balai Penelitian Tanaman Pangan Sukamandi, Subang.

52. Utama, M. Z. H. 2015. Budidaya Padi Lahan Marjinal Kiat Meningkatkan Produksi Padi. Yogyakarta: Andi.

53. Walisinghe, B. R., Ratnasiri, S., Rohde, N., \& Guest, R. 2017. Does agricultural extension promote technology adoption in Sri Lanka. International Journal of Social Economics.

54. Wibowo, K., Balla, P. T., \& Kaharuddin. 2014. Respons petani terhadap penerapan sistem tanam jajar legowo 2:1. Jurnal Agrisistem: Seri Sosek dan Penyuluhan, 10(2), 100-106.

55. Yunus, Hadi Sabari. 2010. Metodologi Penelitian Wilayah Kontemporer. Yokyakarta: Pustaka Pelajar.

How to cite this article: Anida RE, Ayu SF, Wibowo RP. The affecting factors of jajar legowo planting systems adoption in Barumun Tengah District, Padang Lawas Regency. International Journal of Research and Review. 2021; 8(4): 70-78. DOI: $\quad$ https://doi.org/ 10.52403/ ijrr.20210411 